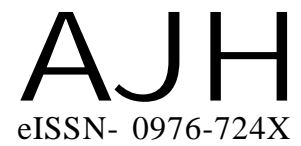

Received : 06.07.2016

Revised : 18.10 .2016

Accepted : 03.11.2016

AUTHOR FOR CORRESPONDENCE

C. THANGAMANI

Horticultural Research Station

(T.N.A.U.), KODAIKANAL, (T.N.)

INDIA

Email : thangamani.sk@gmail.com
THEASIAN JOURNALOF HORTICULTURE

Volume 11 | Issue 2 | December, 2016 | 313-318

Visit us -www.researchjournal.co.in

RESEARCH PAPER

DOI : 10.15740/HAS/TAJH/11.2/313-318

\section{Genetic analysis in bitter gourd (Momordica charantia L.) for yield and component characters}

\section{THANGAMANI}

ABSTRACT : In a full diallel analysis ten parents of bitter gourd were used to study the inheritance of yield, yield contributing characters and quality characters. Data from the ten parents and their resultant 90 hybrids were analyzed. The estimates of $\hat{\mathrm{D}}$ (additive effects) were significant for 13 characters in season I and 15 characters in season II out of 17 characters studied. The estimates of ' $\mathrm{H}_{1}$ ' and ' $\mathrm{H}_{2}$ ' were positive and significant for all the traits. It indicated that there was unequal frequency of alleles at all loci. Further the proof for the unequal distribution of the alleles over loci was obtained by the ratio of $\mathrm{H}_{2} / 4 \mathrm{H}_{1}$. The estimates of ' $\mathrm{F}$ ' were positive for all the traits studied. It indicated the pre-dominance of dominant alleles in the parents and this was supported by the ratio $\left(\mathrm{K}_{\mathrm{D}} / \mathrm{K}_{\mathrm{R}}\right)$ of dominant to recessive alleles in the parents, the ratio was more than one for all the traits studied. The mean degree of dominance over all loci indicated over dominance for 11 characters in season I and 10 characters in season II. Narrow sense heritability estimates were high for seven out of 17 characters studied and for the remaining ten characters it was low in both the seasons. The preponderance of dominant gene action coupled with low narrow sense heritability observed for the traits viz., days to first male and female flower appearance, fruit flesh thickness (season II), number of fruits per vine (season I), yield of fruits per vine, ascorbic acid and iron content revealed the importance of heterosis breeding for simultaneous improvement of yield and quality characters.

KEY WORDS : Momordica charantia L., Diallel analysis, Gene action, Earliness, Yield , Quality traits

HOW TO CITE THIS ARTICLE : Thangamani, C. (2016). Genetic analysis in bitter gourd (Momordica charantia L.) for yield and component characters. Asian J. Hort., 11(2) : 313-318, DOI : 10.15740/HAS/ TAJH/11.2/313-318. 